\title{
UTILIZATION OF AMYLASE FROM DURIAN SEED SPROUTS TO CONVERT DURIAN STARCH INTO GLUCOSE SYRUP
}

\author{
M. Zulham Efendi Sinaga ${ }^{1,2, 凶}$, Cut Fatimah Zuhra ${ }^{1,2}$, Emma Zaidar, ${ }^{1,2}$, \\ Rumondang Bulan ${ }^{1}$, Firman Sebayang ${ }^{1}$, Rini Hardiyanti ${ }^{1,2}$ \\ and Dea Rahmadana ${ }^{1}$ \\ ${ }^{1}$ Department of Chemistry, Faculty of Mathematics and Natural Sciences, \\ Universitas Sumatera Utara, Medan 20155, Indonesia \\ ${ }^{2}$ Pusat Unggulan Iptek (PUI) Kitosan dan Material Maju, Universitas Sumatera Utara, \\ Medan 20155, Indonesia \\ ${ }^{\square}$ Corresponding Author: m.zulham.effendi@usu.ac.id
}

\begin{abstract}
A high abundant yet available durian seeds as wastes from fruit consumption in North Sumatera, Indonesia may be utilized as a potential source of natural amylase. This study investigated the potential of isolated amylase from durian seed sprouts and its utilization in producing glucose syrup. The yield of amylase from durian seed sprouts $(150 \mathrm{~g})$ was $0.33 \%$ with optimum activities at $40{ }^{\circ} \mathrm{C}, \mathrm{pH} 7.0$, and $1 \%(\mathrm{w} / \mathrm{v})$ substrate hydrolysis. Partial purification of amylase was precipitated under $60 \%(\mathrm{w} / \mathrm{v})$ ammonium sulfate which showed an increase in enzyme activity $(43.48 \pm 0.32 \mathrm{U} / \mathrm{mL})$. The crude enzymes $(1 \%)$ were then tested to hydrolyze durian starch into glucose syrup. The glucose syrup were characterized based on dextrose equivalent value $(48.25 \% \pm 0.09)$, reducing sugar content $(38.10 \% \pm 0.04)$, water content $(17.35 \% \pm 0.09)$, ash content $(0.44 \% \pm 0.12)$, and viscosity $(300.48 \mathrm{cP} \pm 1.07)$. The production of glucose syrup was successfully achieved using the natural amylase derived from durian sources.
\end{abstract} Keywords: Amylase, Durian Starch, Durian Seed Sprouts, Glucose Syrup, Reducing Sugar, Waste Utilization

RASĀYAN J. Chem., Vol. 14, No.3, 2021

\section{INTRODUCTION}

Durian is one of the favorite fruits consumed by people in the tropical region including Indonesia due to its unique taste and aroma. During fruit processing, a large portion of waste is produced in the form of seeds which composed one-third of the edible parts of the fruits. ${ }^{1,2}$ Durian seeds contain carbohydrates in the form of starch which can be used as a source for producing glucose syrup. ${ }^{3}$ Glucose syrup is a product made from glucose, maltose and other saccharin derived from starch. ${ }^{4}$ Glucose syrup is mainly produced under two mechanisms, e.g., (1) chemical hydrolysis of starch using strong acids (i.e., hydrochloric acid) ${ }^{3}$ and (2) through natural enzymatic breakdown using amylase. ${ }^{5,6}$ Acid hydrolysis of starch has several disadvantages due to the use of corrosive materials which may harm the environment. As an alternative, the utilization of enzymes in starch hydrolysis is more preferred because it is controllable, effective at room temperature, and does not produce any hazardous by-products.

Amylases are widely applied in industries such as textiles, pharmaceuticals, paper (pulp and paper), feed, detergents and the food industry. ${ }^{7,8}$ In the food industry, the enzyme plays an important role, for example in the manufacture of syrups and sweeteners, bread making, cereal-based products, and also beverages. Based on the broad application of amylases, the enzyme has a strategic market share, which is around $25 \%$ in the global market demand. ${ }^{9}$

Amylases are abundantly present in biological sources from animals, plants, fungi, and microorganisms. ${ }^{10}$ In plants, amylases are mostly produced in seeds, which are needed during seed germination to break down available starch into food sources for embryonic growth and development. ${ }^{11}$ Based on these perspectives, the objective of this study is to initiate the isolation of amylases from durian seed sprouts to 
RASĀYAN J. Chem.

Vol. 14 | No. 3 |2104-2110| July - September | 2021

assess their potential in converting durian starch into glucose syrup. This study was also stimulated by the abundance of durian seeds as wastes in Medan City which may be utilized into a more valuable product.

\section{Isolation and Partial Purification of Amylase}

\section{EXPERIMENTAL}

Durian seeds were washed under running tap water. Pulp medium was prepared for seed germination in a container. Germinated seeds (Fig.-1) grown on 2 days were weighed for $150 \mathrm{~g}$ and homogenized with 250 $\mathrm{mL}$ of $1 \% \mathrm{NaCl}$ solution in cold conditions. The slurry was centrifuged at $10,000 \mathrm{rpm}$ at $20{ }^{\circ} \mathrm{C}$ for 10 min. Supernatants were tested for its activity under different incubation temperature $(30,35,40,45,50$ $\left.{ }^{\circ} \mathrm{C}\right), \mathrm{pH}(3,5,7,8)$, and starch concentration $(0.5,1,1.5,2,2.5 \%)$. After obtaining the optimum condition, the crude enzymes were partially purified using the ammonium sulphate precipitation technique with 60 $\%(\mathrm{w} / \mathrm{v})$ of saturation. The solution was kept at room temperature overnight. The solution was centrifuged at $10,000 \mathrm{rpm}$ at $20^{\circ} \mathrm{C}$ for $30 \mathrm{~min}$. Pellets were harvested and dissolved into phosphate buffer in a dialysis bag. The enzymes were incubated under constant agitation for $8 \mathrm{hr}$ at room temperature. The enzymes were reacted with $\mathrm{BaCl}_{2}$ to ensure no contamination of ammonium salts. The partially purified enzymes were then concentrated in a freeze dryer. The scheme of isolation and partial purification of amylase can be seen in Fig.-2.

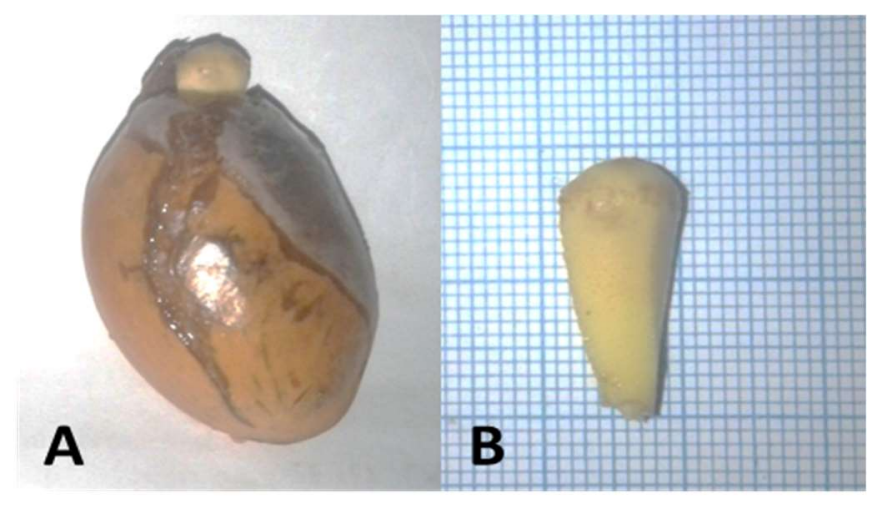

\section{Characterization of Amylase Activity}

Fig.-1: (A.) Durian Seed, (B.) Germinated Durian Seed or Sprouts.

Determination of optimum amylase activity was performed in a $1.5-\mathrm{mL}$ reaction volume composed of 1 $\mathrm{mL}$ of crude enzymes with $0.5 \mathrm{~mL}$ of substrate with different concentrations $(\%, \mathrm{w} / \mathrm{v})$ and different incubation temperatures and $\mathrm{pH}$ as previously described. Amylase activity was determined using NelsonSomogyi method in which one unit of amylase activity was the amount of $0.18 \mathrm{mg}$ of reducing sugar $(1 \mu \mathrm{mol})$ released during enzymatic reaction per $\mathrm{mL}$ of enzyme in an optimum condition. ${ }^{12,13}$

\section{Preparation of Durian Starch}

One kg of clean durian seeds was thinly sliced into smaller pieces. The durian pieces were further washed under running tap water to remove excessive mucus. The durian pieces were mashed using a blender in a ratio of 10:1 in water. The slurry was let stand for $6 \mathrm{hr}$ to form two layers of precipitates and filtrates. The precipitates were washed with aquadest and kept for $24 \mathrm{hr}$. The precipitates were dried in an oven at $40{ }^{\circ} \mathrm{C}$ to obtain durian starch. The starch was tested qualitatively using iodine solution and FT-IR spectra by comparing its functional group to commercial starch.

\section{Production of Glucose Syrup}

Durian starch was dissolved in water with a ratio of 10:1 (w/v) and added with amylases under different concentration $(0.25,0.5,0.75,1.0 \%)$ for $120 \mathrm{~min}$ for total liquefaction. The dextrin portion from the starch solution was cooled to $60{ }^{\circ} \mathrm{C}$ with continuous stirring for $72 \mathrm{hr}$. Bleaching was achieved by adding $0.5 \%$ of activated carbon into the solution. The solution was filtered and evaporated to obtain glucose syrup. 
RASĀYAN J. Chem.

Vol. 14 | No. 3 |2104-2110| July - September | 2021

\section{Physicochemical Characteristics of Glucose Syrup}

Viscosity (cP) of glucose syrup was tested using an Ostwald viscometer. Reducing sugar content was determined using Luff Schoorl method by reacting a $25-\mathrm{mL}$ Luff Schoorl solution with glucose syrup and heated for $10 \mathrm{~min}$. The mixture was added with $15 \mathrm{~mL}$ of $20 \% \mathrm{KI}$ and $25 \mathrm{~mL}$ of $25 \%(\mathrm{v} / \mathrm{v}) \mathrm{H}_{2} \mathrm{SO}_{4}$. The mixture was titrated with $0.1 \mathrm{~N} \mathrm{Na}_{2} \mathrm{~S}_{2} \mathrm{O}_{3}$ until becoming pale yellow. While titrating, $0.5 \%$ amylum indicator was then added into the solution until it turned to a milky white appearance. The concentration of reducing sugar (\%) was converted from the remaining $\mathrm{Na}_{2} \mathrm{~S}_{2} \mathrm{O}_{3}$ solution during the titration. Dextrose equivalent was measured by comparing the amount of reducing sugars in glucose syrup with its total sugar content as a percentage on a dry basis. Water content (\%) was determined based on Indonesian National Standards (SNI 01-2891-1992) by heating a $2 \mathrm{~g}$ sample of glucose syrup in an oven at $105{ }^{\circ} \mathrm{C}$ for $3 \mathrm{hr}$ until constant weight. Ash content (\%) was also determined based on SNI 01-2891-1992 by drying a $2 \mathrm{~g}$ sample of glucose syrup in a furnace at $600{ }^{\circ} \mathrm{C}$ for $6 \mathrm{hr}$ until constant weight.

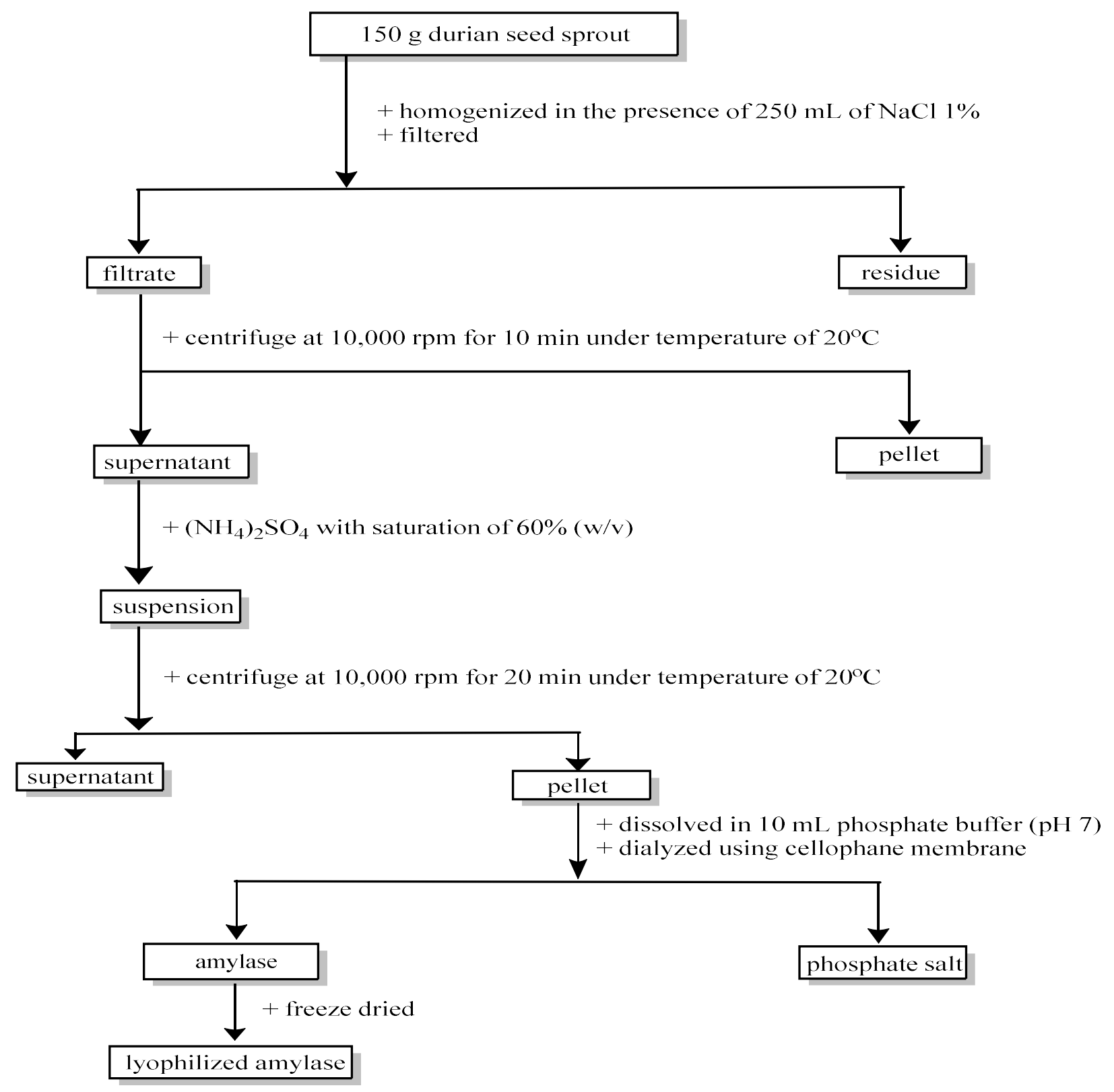

Fig.-2: Scheme of Isolation and Purification of Amylase 


\section{Amylase Activity of Durian Seed Sprouts}

\section{RESULTS AND DISCUSSION}

Determination of amylase activity was based on Nelson-Somogyi's method of quantifying reducing sugar content. The optimum activity was determined by testing the enzyme activity in different incubation temperatures, $\mathrm{pH}$, and substrate concentration. Based on the results, the optimum activity was achieved at $40{ }^{\circ} \mathrm{C}$ with an activity of $39.56 \pm 0.36 \mathrm{U} / \mathrm{mL}$, at $\mathrm{pH} 7.0$ with $40.36 \pm 0.11 \mathrm{U} / \mathrm{mL}$, and $1 \%$ of substrate concentration with $27.10 \pm 0.03 \mathrm{U} / \mathrm{mL}$ (Fig.-3). The crude amylases from durian sprouts showed considerable enzyme activities despite its limited yield or only $0.33 \%(\mathrm{w} / \mathrm{v})$ of the total mass. Amylases originated from different sources may exhibit different optimum activities. Most reports on amylases were focused on microbial sources with varying optimum conditions such as those isolated from Bacillus sp. $\left(\mathrm{pH} \mathrm{9.0,65}{ }^{\circ} \mathrm{C}\right)^{14}$ and Aspergillus niger $\left(\mathrm{pH} 6.0,45^{\circ} \mathrm{C}\right)^{15}$. Meanwhile, amylases isolated from wheat seeds (Triticum aestivum) produced an optimum activity at $\mathrm{pH} 5.0$ and $68{ }^{\circ} \mathrm{C} .{ }^{16}$
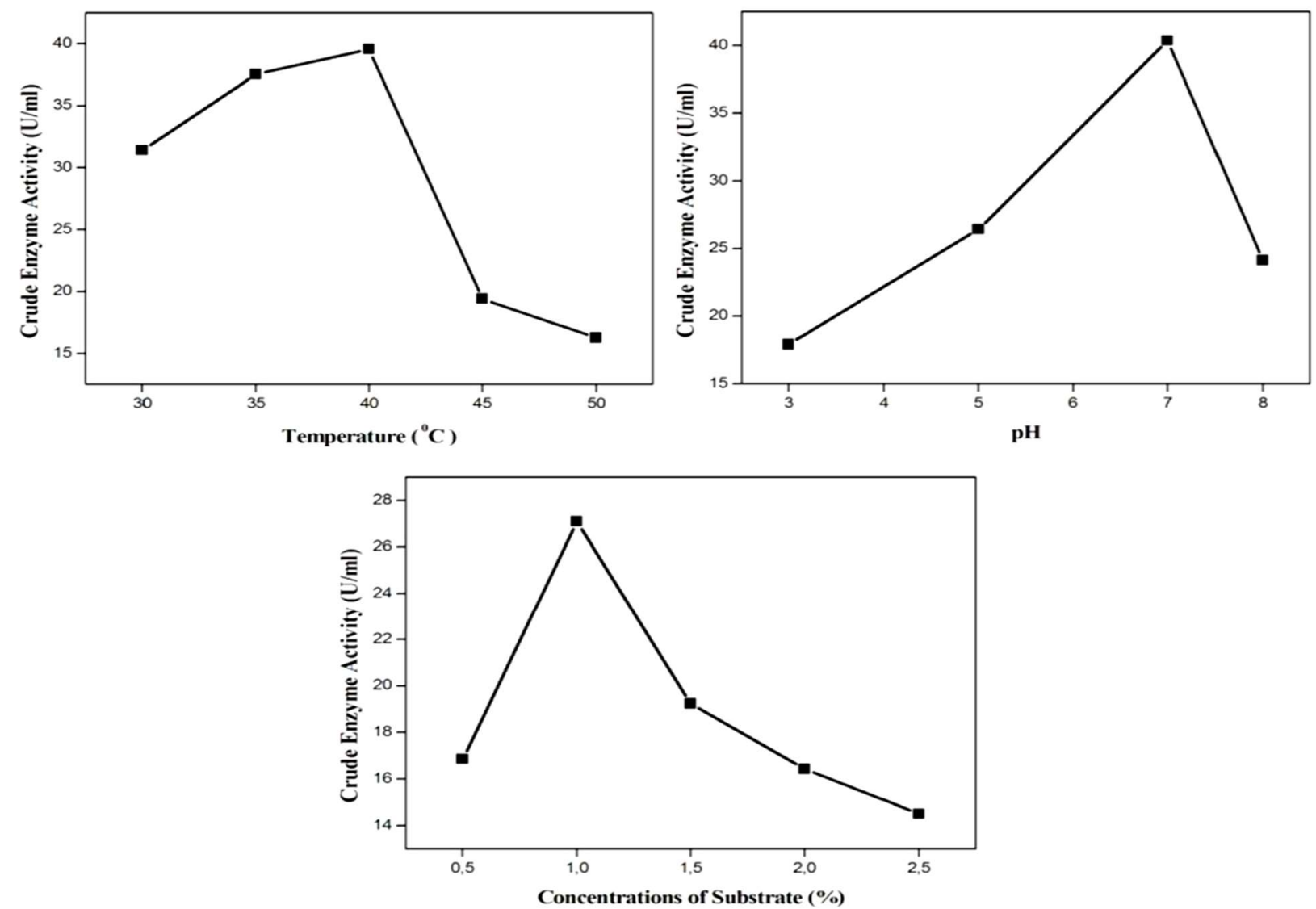

Fig.-3: Effect of Incubation Temperature, pH, and Substrate Concentration on the Rate of Starch Hydrolysis by Crude Amylases from Durian Seed Sprouts

After determining the optimum condition for amylases, the crude enzymes were purified through dialysis and ammonium sulphate precipitation $(60 \%)$ which produced an elevated activity of $43,48 \pm 0,32 \mathrm{U} / \mathrm{mL}$. This is due to the separation of protein in the enzyme solution from the water molecule under competition with the ammonium salt ions. The salt ions have a greater affinity than the enzyme protein so that the protein concentration is higher in the solution which leads to the increased enzyme activity. ${ }^{17,18}$

\section{Characteristics of Durian Starch}

The source of starch in the production of glucose syrup was isolated from durian seeds. One $\mathrm{kg}$ of durian seeds yielded as much as $55 \mathrm{~g}$ of starch $(5.5 \%)$ which were confirmed and compared to commercial starch products (Fig.-4). Based on the characterization results, the durian starch (Fig.-4A) was obtained in 
RASĀYAN J. Chem.

Vol. 14 | No. 3 |2104-2110| July - September | 2021

white powder similar to sago and cassava starch. The color change from white into blue/black color was produced after reacting the starch solution with iodine's solution (Fig.-4B).

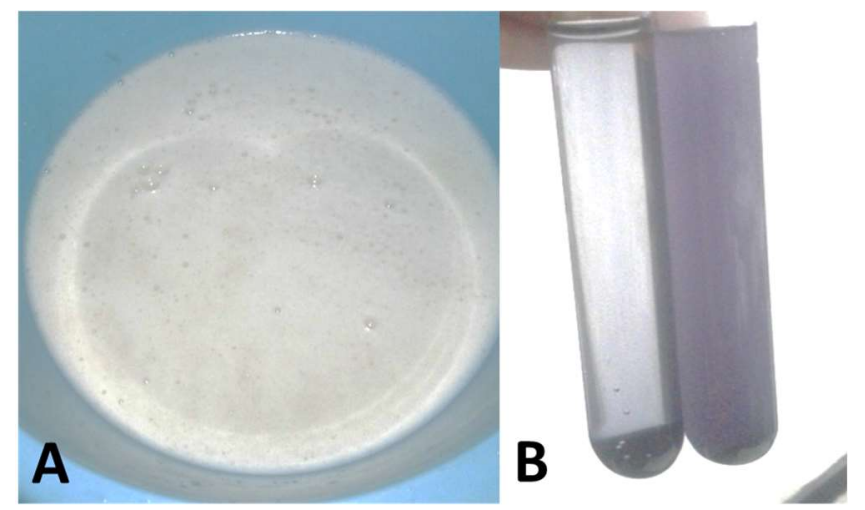

Fig.-4: (A) Durian Starch, (B) Iodine's Test.

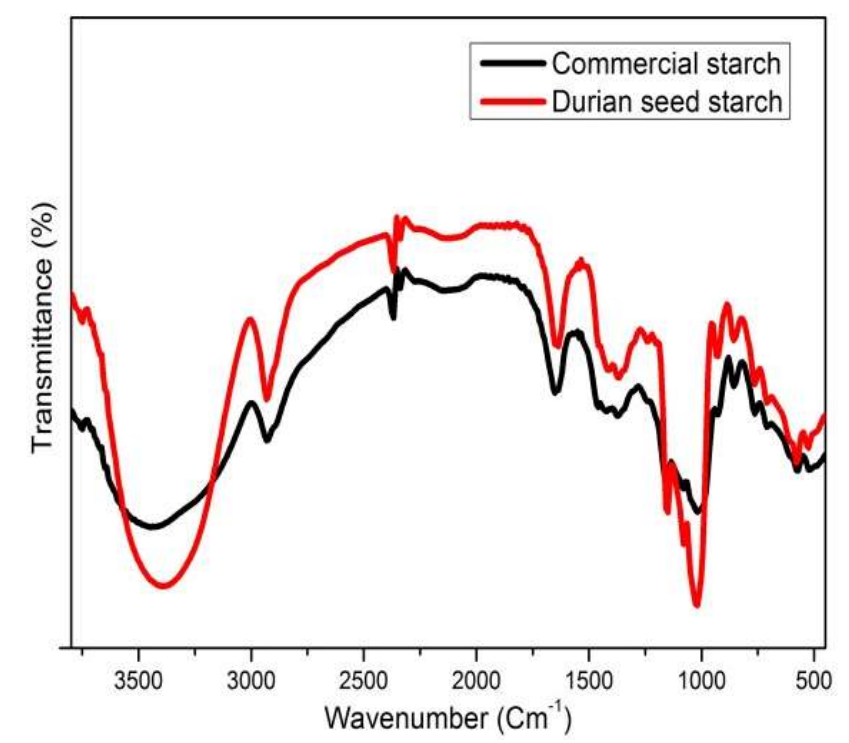

Fig.-5: FT-IR Spectra of Native Durian Seed and Commercial Starch

Based on IR spectra, the functional groups in durian starch were similar to commercial starch (Fig.-5). The vibrational peaks were detected at $3387.00 \mathrm{~cm}^{-1}$ showing O-H stretching, $2931.80 \mathrm{~cm}^{-1}$ showing C-O stretching, $1604.77 \mathrm{~cm}^{-1}$ showing $\mathrm{C}-\mathrm{O}$ bending associated with $\mathrm{OH}$ group, $1018.41 \mathrm{~cm}^{-1}$ showing $\mathrm{C}-\mathrm{O}$ stretching, and C-O-C ring vibration of carbohydrate supported by detection at $925.83 \mathrm{~cm}^{-1}, 856.39 \mathrm{~cm}^{-1}$, and $786.96 \mathrm{~cm}^{-1} 19$. In addition, proximate analysis of durian seed starch showed an estimate of nutritional composition as appointed from its high content of carbohydrate to be used in glucose syrup production (Table-1).

Table-1: Proximate Analysis Results of Durian Seed Starch

\begin{tabular}{c|l|c}
\hline No & \multicolumn{1}{|c|}{ Component(s) } & Percentage $( \pm$ S.D $)$ \\
\hline 1 & Water & $1.10 \pm 0.14$ \\
\hline 2 & Lipid & $1.06 \pm 0.10$ \\
\hline 3 & Fiber & $1.30 \pm 0.07$ \\
\hline 4 & Protein & $4.76 \pm 0.17$ \\
\hline 5 & Ash & $0.25 \pm 0.04$ \\
\hline 6 & Carbohydrate & $55.45 \pm 0.47$ \\
\hline
\end{tabular}


RASĀYAN J. Chem.

Vol. 14 | No. 3 |2104-2110| July - September | 2021

\section{Production of Glucose Syrup}

The step in producing glucose syrup was initiated by dissolving durian starch into water $(10 \%, \mathrm{w} / \mathrm{v})$ then reacted with partial amylases $(0.25,0.5,0.75,1.0 \%)$ and commercial amylase $(1 \%)$ as a comparison. The conversion of starch into glucose syrup was successfully achieved with each characteristic as presented in Table-2.

Table-2: Quality Assessment Results of Glucose Syrup produced from Durain Starch

\begin{tabular}{c|l|c|c|c|c|c}
\hline No & \multicolumn{1}{|c|}{ Treatment } & $\begin{array}{c}\text { Dexrose } \\
\text { Equivalent } \\
(\%)\end{array}$ & $\begin{array}{c}\text { Reducing } \\
\text { Sugar } \\
(\%)\end{array}$ & $\begin{array}{c}\text { Water } \\
\text { Content } \\
(\%)\end{array}$ & $\begin{array}{c}\text { Ash Content } \\
(\%)\end{array}$ & $\begin{array}{c}\text { Viscosity } \\
(\mathrm{cP})\end{array}$ \\
\hline 1 & $\begin{array}{l}\text { Starch 10\%+1 \% } \\
\text { Commercial Amylase }\end{array}$ & $50.68 \pm 0.07$ & $40.02 \pm 0.04$ & $16.59 \pm 0.12$ & $0.41 \pm 0.11$ & $341.44 \pm 1.41$ \\
\hline 2 & $\begin{array}{l}\text { Starch 10\%+1 \% } \\
\text { Partial Enzyme }\end{array}$ & $48.25 \pm 0.09$ & $38.10 \pm 0.04$ & $17.35 \pm 0.09$ & $0.44 \pm 0.12$ & $300.48 \pm 1.07$ \\
\hline 3 & $\begin{array}{l}\text { Starch 10\%+0.75\% } \\
\text { Partial Enzyme }\end{array}$ & $44.59 \pm 0.08$ & $35.21 \pm 0.05$ & $17.43 \pm 0.11$ & $0.44 \pm 0.09$ & $214.29 \pm 1.56$ \\
\hline 4 & $\begin{array}{l}\text { Starch 10\%+ 0.5\% } \\
\text { Partial Enzyme }\end{array}$ & $40.26 \pm 0.06$ & $31.79 \pm 0.06$ & $19.53 \pm 0.11$ & $0.56 \pm 0.11$ & $181.74 \pm 1.41$ \\
\hline 5 & $\begin{array}{l}\text { Starch 10\%+0.25\% } \\
\text { Partial Enzyme }\end{array}$ & $37.48 \pm 0.05$ & $29.60 \pm 0.07$ & $21.46 \pm 0.13$ & $0.51 \pm 0.09$ & $178.80 \pm 1.36$ \\
\hline
\end{tabular}

Based on Table-2, it can be seen that the dextrose equivalent (DE) value increased following the concentration of amylases. The DE value may indicate the extent of converted starch into glucose through enzymatic reactions, by comparing it to pure glucose which possesses a DE value of $100 \%{ }^{20,21}$. At a concentration of $1 \%$ amylases, the disparity between commercial and purified amylases was not significant, which indicates that the purified amylases were in optimum state. To be acceptable in the market, the DE value of glucose syrup must be adjusted from 39.0 to $46.5 \%$. Our results then showed the acceptable condition from each treatment with an exception of $0.25 \%(\mathrm{w} / \mathrm{v})$ treatment.

Likewise, the greater the reducing sugar content also followed the amount of applied amylases. Based on the Indonesian National Standard (SNI 01-3544-1994), it was required that the reducing sugar content in glucose syrup be adjusted at least $30 \%$. Meanwhile, the water and ash content based on the standard must be adjusted at $20 \%$ and $1 \%$, respectively. The viscosity of syrup is related to the amount of water content in the syrup. The results showed that only in $0.25 \%$ treatment, the viscosity was not achieved. Therefore, the resulting glucose syrup at a concentration of $1 \%(\mathrm{w} / \mathrm{v})$ amylase showed the best viscosity value.

\section{CONCLUSION}

Amylases isolated from germinated durian seeds showed an increase of activity after ammonium salt precipitation and dialysis with an activity of $43.48 \pm 0.32 \mathrm{U} / \mathrm{mL}$. The enzymes were utilized to produce glucose syrup from durian starch as a substrate. The resulting glucose syrup at a concentration of $1 \%$ (w/v) was considered as the best formulation based on its qualities i.e. dextrose equivalent (DE) value, reducing sugar content, water content, ash content, and viscosity.

\section{ACKNOWLEDGEMENT}

The authors would like to express the highest gratitude to the Rector of Universitas Sumatera Utara for funding our project under contract by Lembaga Penelitian USU (4167/UN5.1.R/PPM/2019) in April 2019.

\section{REFERENCES}

1. M.M. Ali, N. Hashim, S.A. Aziz, O. Lasekan, Food Control, 113, 107189(2020), https://doi.org/10.1016/j.foodcont.2020.107189

2. X.Y. Tan, A. Misrana, L.D.J. Daim, B.Y.C. Lau, Food Chemistry, 343, 128471(2021), https://doi.org/10.1016/j.foodchem.2020.128471

3. S. Baraheng, T. Karrila, Food Bioscience, 30, 100412(2019), https://doi.org/10.1016/j.fbio.2019.100412 
RASĀYAN J. Chem.

Vol. 14 | No. 3 |2104-2110| July - September | 2021

4. J.C. Acosta-Pavas, L. Alzate-Blandon, A.A. Ruiz-Colorado, DYNA, 87(214), 173(2020), https://doi.org/10.15446/dyna.v87n214.82669

5. P. Mokrejs, D. Janacova, K. Kolomaznik, P. Svoboda, Rasayan Journal of Chemistry, 4(1), 180(2011).

6. R.d.R.O. de Barros, P. Becarelli, R.A. de Oliveira, L. Tognotti and E.P.d.S. Bon, Biochemical Engineering Journal, 151, 107340(2019), https://doi.org/10.1016/j.bej.2019.107340

7. J. John, International Journal of Bioinformatics and Biological Science, 5, 41(2017), https://doi.org/10.5958/2321-7111.2017.00006.3

8. N. Raman, C. Pothiraj, Rasayan Journal of Chemistry, 1(3), 537(2008).

9. R. Sindhu, P. Binod, A. Madhavan, U.S. Beevi, A.K. Mathew, A. Abraham, A. Pandey and V. Kumar, Bioresource Technology, 245, 1740(2017), https://doi.org/10.1016/j.biortech.2017.04.098

10. M.E. Ojewumi, O.A. Adeeyo, O.M. Akingbade, D.E. Babatunde, A.A. Ayoola, O.O. Awolu, E.O. Ojewumi and O.J. Omodara, International Journal of Pharmaceutical Sciences and Research, 9, 3378(2018), https://doi.org/10.13040/IJPSR.0975-8232.9(8).3378-87

11. R. Joshi, International Journal of Creative Research Thoughts, 6, 1481 (2018).

12. K. Luo, N.G. Kim, S.M. You and Y.R. Kim, Nanomaterials, 9(9), 1291(2019), https://doi.org/10.3390/nano9091291

13. D. Oktiarni, Lusiana, F.Y. Simamora and J.M.L. Gaol, AIP Conference Proceedings, 1677, 090004(2015), https://doi.org/10.1063/1.4930749

14. A.A. Simair, A.S. Qureshi, I. Khushk, C.H. Ali, S. Lashari, M.A. Bhutto, G.S. Mangrio and C. Lu, BioMed Research International, 2017, 9173040(2017), https://doi.org/10.1155/2017/9173040

15. A. Behailu and G. Abebe, International Journal of Biotechnology and Molecular Biology Research, 9, 7(2018), https://doi.org/10.5897/ijbmbr2018.0289

16. K. Singh and A.M. Kayastha, Food Chemistry, 162, 1(2014), https://doi.org/10.1016/j.foodchem.2014.04.043

17. N. Suresh, A. Das, N.S. Vasanthi, Rasayan Journal of Chemistry, 6(4), 292(2013).

18. A. Winarti, N.A. Fitriyanto, Jamhari, A. Pertiwiningrum, Z. Bachruddin, Y. Pranoto and Y. Erwanto, Chemical Engineering Transactions, 63, 709(2018), https://doi.org/10.3303/CET1863119

19. A.H.D. Abdullah, S. Chalimah, I. Primadona and M.H.G. Hanantyo, IOP Conference Series: Earth and Environmental Science, 160, 012003(2018), https://doi.org/10.1088/1755-1315/160/1/012003

20. J. Eke-Ejiofor, International Journal of Recent Scientific Research, 6, 4400(2015).

21. L. Hoobs, 2009, Sweeteners from Starch: Production, Properties and Uses, in: J. BeMiller and R. Whistler $\left(3^{\text {rd }}\right)$, Starch: Chemistry and Technology, Academic Press, United States, pp. 797-832, https://doi.org/10.1016/b978-0-12-746275-2.00021-5

[RJC-6361/2021] 